\title{
Coaching Disadvantaged Young People: Evidence from Firm Level Data
}

\author{
Jens Mohrenweiser* and Friedhelm Pfeiffer** \\ * Centre for European Economic Research (ZEW) \\ ** Centre for European Economic Research (ZEW) \& University of Mannheim
}

\begin{abstract}
In Germany, apprenticeship training firms currently face a shrinking number of qualified school-leavers because of smaller birth cohorts and an increasing proportion of school leavers aiming for higher education. This paper investigates whether a programme that supports firms to train disadvantaged youth can reduce recruiting difficulties in apprentice training firms. Based on unique firm-level data from the metal and electronic industry in Baden-Württemberg from 2010 to 2013, we apply instrumental variable and difference-indifference estimations and find no significant short-term causal impact of the programme.
\end{abstract}

Keywords: disadvantaged youth, apprenticeship training, programme evaluation JEL-Classification: J11, J24, M51, L60.

Acknowledgements: The data have been collected during a research project financed by Südwestmetall, the Baden-Württemberg Employer Association of the Metal and Electronic Industry. We thank Südwestmetall for generous support and the allowance for using the data for our research and Klaus-Peter Becker, Tina Hinz, Heinrich Kögel and Philipp Selent for research assistance. Furthermore, we thank two anonymous referees and Bernd Fitzenberger for valuable comments on an earlier version of our paper. The views expressed in this article are those of the authors and do not necessarily reflect the views of Südwestmetall. All opinions and mistakes are our own.

Corresponding author: Jens Mohrenweiser, Centre for European Economic Research, P.O. Box 1034 43, D68034 Mannheim, mohrenweiser@zew.de 


\section{Introduction}

After decades with excess supply, the number of apprenticeship positions in Germany exceeds the number of applicants since a few years, particularly in manufacturing occupations (Ulrich et al. 2014). Training firms face a novel situation that they can't fill all apprenticeship vacancies with qualified school-leavers. To solve this problem, employers have in principle four options: first, they can lower their hiring criteria for apprenticeships, second they can try to influence the proportion of school-leavers who are interested in an apprenticeship in manufacturing occupations. Third they can attempt to increase the number of applicants with adolescents coming from other regions and, fourth, they can reduce training intensity.

While firms presumably experiment with several options, Südwestmetall, the employer association of the metal- and electronic industry in Baden-Württemberg, initiated a programme that supports member firms to use the first option and train disadvantaged youth who do not meet the current hiring standards. Since disadvantaged youth require not only more training resources (e.g. time for instructions) but also additional pedagogical skills of training instructors (see section 2), the employer association provides and finances social workers for doing these jobs. The social workers offer coaching, organise additional lessons in vocational and general subjects (math, German) and train social skills in the first apprenticeship training year. Each social worker is responsible for 15 apprentices in several firms.

Our paper investigates whether the programme can reduce recruiting difficulties of firms in the metal- and electronic industry. The programme may increase the number of potential applicants and participating firms learn to address the special needs of disadvantaged youth to train them properly. For the empirical analysis, we use a unique panel data set covering more than 85 per cent of eligible member firms of the employer association in the metal and elec- 
tronic industry in Baden-Württemberg during the period 2010 to $2013^{1}$. The survey asks apprentice training instructors in member firms in each summer about apprentice intakes, retention, organisation and execution of regular apprenticeship training, recruiting strategies and further apprenticeship training related topics.

We apply a difference-in-difference and an instrumental variable approach to estimate the effect of the programme on the probability that firms report a vacancy. We find no significant short term direct effect of the programme, neither on the probability to reduce vacancies for apprentices, or on the reduction of the overall number of open vacancies for apprentices or on the share of vacancies for apprentices on total intakes.

To the best of our knowledge, our paper is the first to assess whether a coaching programme for disadvantaged apprentices can mitigate firms’ recruitment difficulties for apprentices. Beyond the recruitment difficulties of firms, the programme design is of interest given the unsettled debate whether disadvantaged youth should be trained in schools or in firms. On the one hand, classroom teaching may be more effective to train cognitive and non-cognitive skills of disadvantaged youth because teachers can directly address their needs (Pohl/Walther 2007). On the other hand, firms provide a training environment that motivates adolescents by doing practically relevant tasks as part of the workforce (Dolton et al. 1994; Ryan 2012).

Effective integration of disadvantaged youth into apprenticeships is of public interest since a delayed entry into vocational training and into the labour market may lead to lower earnings trajectories and a higher probability of unemployment over the life span (Inkmann et al. 1998; Franz et al. 2000, Möller/Umkehrer 2014).

\footnotetext{
${ }^{1}$ Furthermore the authors performed interviews in six participating and six non-participating member firms as well as with four responsible social workers to better understand firm's decision for programme participation and potential outcomes.
} 
The paper has the following structure. Section 2 introduces the intervention. Section 3 elaborates on the econometric methods and Section 4 describes data and variables used. Section 5 discusses our main descriptive and analytical findings. Section 6 concludes.

\section{Programme Description}

In the year 2010 Südwestmetall, the employer association of the metal and electronic industry in Baden-Württemberg, started a programme to support apprenticeship training of disadvantaged youth ${ }^{2}$. The employer association introduced the programme because member firms experienced a shrinking number of qualified school-leavers as a result of declining fertility in Germany and Baden-Württemberg and an increasing propensity of school-leavers aiming for higher education. The programme should extend the potential number of apprentices to those disadvantaged youth who has not been in focus of member firms and support member firms with expertise to cope with the special needs of disadvantaged youth. The employer association aims to reduce the apprenticeship recruitment difficulties in member firms by targeting disadvantaged young adults and commissioned a training provider to administer the programme and match firms and disadvantaged youth ${ }^{3}$.

Since disadvantaged youth may require not only more training resources, particularly more instruction time, but also additional pedagogical skills of training instructors to address the special needs of disadvantaged youth, social workers, financed by the employer association, offer coaching, additional lessons in vocational and general subjects (math, German) and social skill training for participating apprentices during the first training year. One social worker

\footnotetext{
${ }^{2}$ A detailed description of the intervention programme is available in German language at http://www.bbqzukunftskurs.de/einstiegberufsvorbereitung.html? tx_adobbq_pi1[showUid]=1623\&cHash=817858a83c4 6884574ef3d76ac812cbc.

${ }^{3}$ Two main matching routes exist: First, establishments contact the training provider when they are interested in training of disadvantaged youth and know a candidate from an internship or state-supported integration programmes. Second, the training provider also runs several programmes to support disadvantaged pupils in schools or in vocational preparation programmes and contacts establishments to find an apprenticeship for one of the candidates.
} 
is responsible for 15 participating apprentices in several firms in each of the 13 Südwestmetall districts in Baden-Württemberg.

Who qualifies as a disadvantaged adolescent for this project? The basic idea is that those adolescents qualify for participation whose cognitive capabilities are sufficient to successfully master a high quality apprenticeship training in the metal and electronic industry, but who lack social and non-cognitive skills such as adequate behaviour in conflict situations, resilience, and self-regulation. The lack of such non-cognitive and social skills could be caused in disadvantaged family environment and a lack of family support during young adulthood. ${ }^{4}$ Thus, the basic rationale for the programme is that individual coaching by social workers and additional training can close the skill gap in these non-cognitive skills.

However, the programme does not have formal test procedures to assess cognitive and other competencies of potential applicants. The selection into the programme is rather based on a number of proxies such as disadvantaged family background, migrations status or criminal background to name a few. Unfortunately, we do not know the individual selection criteria and do not have individual data.

\section{Econometric Methods}

We evaluate the impact of the programme on firms' difficulties to fill apprenticeship vacancies by applying two alternative econometric procedures: a difference-in-difference and an instrumental variable approach. In this section we discuss the critical assumptions of both methods for identifying the causal programme impacts.

\section{The difference-in-difference approach}

The difference-in-difference approach assumes parallel trends, i.e. treatment and control firms would, after controlling for observables, develop in a parallel manner without the programme. 
On the one hand, we can reasonably believe that treatment and control firms face the same market for school-leavers and each trend in the market for school-leavers influence treatment and control group similarly. On the other hand, the parallel trend assumption may be violated when firms employ different strategies to cope with potential recruitment difficulties.

In order to get some further insights about the potential violation of our identifying assumption, we asked training instructors and personnel managers in twelve member firms (six participating and non-participating respectively) about firms’ recruiting and training policies in the years 2011 and 2013. The majority of these twelve firms increased their effort to find apprentices in recent years. The most important parallel policy to attract school-leavers turned out to be acquisitions in schools.

Firms increasingly participate in technology lessons in schools where they present, for example, the functionality of cogs and its use in manufacturing. Such lessons demonstrate practical importance and advertise the training firm. After such lessons, the number of qualified applications from these schools increased tremendously, the instructors told us. For the same reason, firms are increasingly willing to participate in vocational preparation programmes of schools, offer internships for pupils and a tour around the plant for school classes. As a result from these interviews, we incorporated a variable about school activities of firms in the questionnaire 2011 in order to be able to control for these parallel measures in the econometric analysis. These additional measures are the most important ones according to the responding training instructors and personnel managers. Using this information in the difference-indifference equation enables us to control for relevant alternative firm’s recruitment policies that may otherwise lead to violations in the parallel trend assumption.

The instrumental variable approach

\footnotetext{
${ }^{4}$ Early live adversity (through a disadvantaged family environment) and later psychosocial outcomes are significantly correlated over time; see Blomeyer et al. (2009, 2013), Cunha and Heckman (2007) among others.
} 
The instrumental variable approach requires an instrument that is correlated with programme participation but uncorrelated with the outcome variable of apprenticeship vacancies.

Our instrument is firms' contact with the training provider long before the programme started in 2010, an information available in the data. Prior contacts have been frequent between the training firms and the training provider since more than a decade. In the end of 1990's as the apprenticeship training market was characterized by a strong excess supply due to demographic reasons. Back then, the German government ran a number of programmes to foster apprenticeship training ${ }^{5}$.

In addition, the government discussed a levy for non-training firms to finance additional apprenticeships, a policy which was strongly opposed by employer associations. Instead of such a levy, the employer associations promised to increase the number of apprenticeship positions in the following years. To improve the compliance of their member firms, the employer associations started programmes to increase the number of apprenticeship positions such as subsidized apprenticeships. Südwestmetall commissioned a training provider to administer these programmes in the metal and electronic industry in Baden-Württemberg. The training provider had the task to get in touch with firms to persuade them to increase the number of apprenticeship positions and to offer subsidies.

The same training provider also executes the current programme. Personnel contacts between training provider and training firms in the early 2000's improve the propensity that firms participate in the programme for the disadvantaged youth because training provider and training instructors/ personnel managers know each other. This reduces information and initiation costs. On the contrary, participating in programmes ten years ago, as the apprenticeship training market was characterized by an excess supply, is not very likely to be correlated with potential vacancies for blue-collar manufacturing apprenticeships nowadays. However, even if 
the instrument fulfils the requirement for an instrumental variable, its use is limited since it does not vary over time. As a result we cannot estimate a panel fixed effects IV estimator.

Taken together, the difference-in-difference approach allows us to assess the direct programme effect under the parallel trend assumption while the instrumental variable approach relies on the local effect of the instrument. The combination of both approaches and a number of robustness checks should help us to understand the direct programme effect. These estimates are discussed in section 5.

\section{Data and variables}

\section{Data set and data restrictions}

We use the apprenticeship survey of Südwestmetall from 2010 to 2013. This survey asks apprentice training instructors in member firms in each summer about apprentice intakes, retention and further apprenticeship related topics. The special features of this survey are precise and detailed questions about the organization and execution of apprenticeship training within member firms. This data has not been used before for econometric analysis.

Importantly, programme participation is not self-reported but the training provider reports firms' programme participation. This procedure ensures a more accurate definition of programme participation and avoids misreports which are particularly common when firms attend several programmes and cannot differentiate every funding.

More than 70 per cent of member firms participate in the survey in every year which is an outstanding share for a firm survey. In 2010, 522 firms participated in the survey accounting for 76.9 per cent of all member firms (further numbers and years of participating firms: 2011, 500; 2012, 504; 2013, 491). 621 firms answered the survey in at least one year.

\footnotetext{
${ }^{5}$ Bonin et al. 2010 or Eichhorst et al. 2013 summarize such interventions studies. Some of these programmes have been evaluated scientifically; see for example Caliendo et al. (2011) and Fries et al. (2014).
} 
The data contain 22 firms who participated in all four years between 2010 and 2013 in the programme, 16 (23) firms who participated in three (two) years, and 32 firms who participated ones. We analysed the determinants of these different types of participating firms with probit models and find no meaningful differences ${ }^{6}$. Moreover, the survey does not contain the number of participating apprentices. However, the interview partner told us that as a rule firms train one participating apprentice.

For the difference-in-difference framework we restrict the data to apprenticeship training firms in blue-collar manufacturing occupations that participate at least in two consecutive years in the survey without missing data in relevant variables. Moreover, we exclude firms that participate in every year in the programme and those participating in 2010 since we do not have a reference period for those firms. A reference period before programme participation is necessary for applying the difference-in-difference approach. Moreover, we use the first difference only (programme introduction). The restrictions reduce our final sample from 621 firms with 2,017 observations to 402 firms with 1,351 observations. The sample includes 36 firms who participated in the programme.

In principle, it is not necessary to implement the same data restrictions for the instrumental variable approach. However, for comparison reasons we use the same sample for both estimations. In addition, a robustness check includes also the firms who participated in 2010 in the pilot programme.

\section{Variable definition}

Table 1 displays the definition, mean and standard deviation of the variables used in the econometric analysis. Our main dependent variable is a dummy indicating whether at least one apprenticeship position in blue-collar manufacturing occupations remains vacant, called "vacancy”. This variable indicates firm's difficulties to staff their training positions. 17 per cent

\footnotetext{
${ }^{6}$ The probit results are available upon request from the authors.
} 
of all firms in our final sample report such a vacancy. This number varies between 16 and 18 percent over the years and is slightly increasing over time.

Furthermore, we use the variable "number of vacancies" and "vacancy share" both of which provides additional insights into potential programme effects. The vacancy share is the proportion of vacancies on all apprentice intakes. The vacancy share amounts to 7 percent on average and the number of vacancies to 0.25 per firm. In the sample of firms with vacancies (235 observations) the vacancy share is 38 percent and firms have on average 1.44 vacancies. If a firm hire on average one additional disadvantaged apprentice from the programme, this might have a significant impact on vacancies.

Furthermore, treatment firms hire nearly 33 apprentices in blue-collar manufacturing occupations and firms who do not participate hire 8.3 (not displayed in Table 1). The huge difference is mainly driven by firm size effects. The share of apprentices on total employment is also slightly higher in the participating firms (1.6 percent compared to 1.4 percent in control firms).

The main explanatory variable is firms' programme participation. The variable "treatment" is one, if a firm participates in the particular year in the programme, and zero otherwise. Each year, around 50 firms participate. However, as has already been explained above, we cannot use the 57 participating firms in 2010 since we do not have a reference period for them. This restriction reduces the number of participating firms to 36, accounting for 2.6 per cent of firms in our final sample. In a robustness check, all treatment observation has been included in the IV estimation (see section 5 below and appendix table A2).

We include a number of control variables to depict the heterogeneity in the organisation and execution of apprenticeship training within firms and firms hiring standards that may explain a part of the variation of firm's recruitment strategies. The first set of control variables comprises indicators of the organisation of apprenticeship training within firms: "firm size” (num- 
ber of employees), existence of an "apprentice workshop" and a "full-time training instructor”. Firms processing such equipment as well as large firms are generally considered to have a higher capacity to train apprentices and to cope with problems of individual apprentices (Mohrenweiser 2012; Mühlemann et al. 2013). Moreover, large firms and firms with higher training capacities have usually more resources to run a campaign in schools. They may also have a superior image in the local labour market which is helpful to influence training vacancies. Furthermore, we include a variable about "additional training” that is not included in the training curriculum. This variable may reflect firm's additional training needs and intensity.

Second, we depict firm's intention and knowledge to cope with disadvantaged youth. We take into account if the firm trains apprentices in "two-year apprenticeship" which are usually lowlevel training courses (Mohrenweiser/Zwick 2009; Schönfeld et al. 2010). In addition, we take into account if the firm already trains apprentices that receive additional lessons ("additional support”) in general or vocational subjects to meet exam requirements. Both variables suggest that the firm has experiences with apprentices with presumably inferior performance and can hire from a larger pool of school-leavers which reduces recruitment problems. Furthermore, a dummy indicates if a firm is generally willing to invest "additional resources" for training disadvantaged youth.

Third, we control for the usual hiring standards of training firms in terms of the education background of apprentices with two variables: the proportion of apprentices with one of the lowest secondary school certificate ("Hauptschule” or "Berufsvorbereitungsjahr”, called "Low qualified”) and the proportion of apprentices with the highest secondary school certificate (“Abitur”, termed "High-qualified”). The reference group comprises apprentices with the medium secondary school track certificate ("Realschule”). Firms' that can attract and train school-leavers from all school tracks are less likely to experience vacancies since they can hire from a larger pool of applicants. Moreover, firms that frequently hire school-leavers from 
lower track secondary school are more likely to hire disadvantaged youth. Finally, the longterm "drop-out rate" depicts whether the firm can usually successfully train an entire apprentice cohort (Backes-Gellner/Oswald 2014).

The fourth set of control variables accounts for the general apprenticeship training development in firms. One variable indicates if the firm plans to increase the number of apprentice intakes in the next year and thereby an increasing demand (“intake growth"). Those firms presumably have a higher probability to train disadvantaged youth in order to mitigate recruitment difficulties. The other variable shows if the firm is successful to retain all apprenticeship graduates in blue-collar manufacturing occupations (“leaving graduates”). Since bluecollar manufacturing occupations require net investments in apprenticeship training (Mohrenweiser/Zwick 2009; Schönfeld et al. 2010; Wenzelmann 2012) and member firms are usually obliged by collective agreements to offer each apprenticeship graduate a temporary employment contract, this variable indicates if at least one apprentice decides to leave the firm after training.

Fifth, we control for parallel programmes that take place in firms to cope with recruitment problems. Firms facing difficulties to find qualified school-leavers may use a number of policies to attract school-leavers. The most important policy is the "acquisition" in schools, according to our interviews (see section 3). Training instructors, for example, support teachers in technology lessons and show the functioning of machines, support the vocational preparation programme of schools and offer internships. Such policies aim to increase the number of qualified applicants. Firms with such programmes may either have a lower probability in training disadvantaged youth because they can easily hire more apprentices or they may have a higher probability because of experimenting more actively with various recruiting measures. 


\section{Empirical Findings}

\section{Descriptive statistics}

Since we employ data that has not been utilized for microeconometric research so far, we provide some basic statistics to compare our data with establishments from the metal and electronic industry in Baden-Württemberg in the IAB Establishment Panel, a representative annual establishment survey. In the Südwestmetall Apprenticeship Survey 2010/13, 81 percent of the observations are establishments and 19 percent are companies. We therefore compare establishments in the Südwestmetall Apprenticeship Survey 2010/13 and in the IAB Establishment Panel.

The median firm size in the Südwestmetall Apprenticeship Survey 2010/13 is 241 employees compared to 47 employees in the population of establishment in the sector (own calculation with weighted numbers from the IAB Establishment Panel). Establishments in the sector with a collective bargaining agreement, which can be assumed to be member firms in the employer association, employ 120 employees (median again, according to the IAB Establishment Panel).

Second the proportion of new apprentice intakes on total employment is 1.56 per cent in 2010 in the Südwestmetall Apprenticeship Survey 2010/13 compared to 1.2 per cent in all establishments and 1.1 in establishments with a collective agreement in the IAB Establishment Panel. Taken together, member firms seem to be larger compared to the population of firms in Baden-Württemberg and hire on average more new apprentices.

We proceed with descriptive differences between treatment and control firms in the estimation sample. Table 2 shows differences in our main endogenous variable vacancies in bluecollar apprenticeship positions between treatment and control firms (see table 2 "Vacancy"). On average fewer treatment firms experience vacancies (11 compared to 18 percent). Similarly, the number of vacancies and the vacancy share are also lower in treatment firms. The va- 
cancy share amounts to 2.5 percent in treatments compared 7 percent in control firms and the average number of vacancies is 0.17 in treatment compared to 0.26 in control firms. However the differences are not statistical significant (last row in table 2).

Turning to control variables, treatment and control firms differ furthermore in their organization of apprenticeship training. First, participating firms are larger, more likely to have an apprenticeship workshop and more likely to employ a full-time training instructor. Second, participating firms are more likely to have a higher capacity and knowledge to train disadvantaged youth. In detail, the number of firms with apprentices receiving additional lessons in vocational courses is significantly higher in participating firms. Third, participating firms are more likely to run additional apprentice acquisition policies at local schools. This stresses that our supplementary interviews revealed important insights in apprenticeship acquisition policies. Fourth, participating firms are more likely to had contact to the training provider several years before the implementation of the programme which is a necessary precondition to apply the instrument (81 compared to 42 percent).

\section{Econometric Findings}

Table 3 shows the results of our difference-in-difference estimation. Specification (1) includes only the participation variables, specification (2) ads control variables available in all waves. The third specification (3) ads further control variables that are only available in some waves, which lead to fewer observations. Given the number of observations a p-value lower or equal to five percent indicates significance in statistical terms.

The coefficients of the treatment variable are positive in all specifications (1), (2) and (3). Even if they differ to some degree, the null hypotheses of a zero impact can never be rejected. Hence, the difference-in-difference estimations indicate no significant short-term treatment effect on vacancies from the programme. Note however that the coefficient for participation in specification (3) is -0.114 and significant, i.e. participating firms report lower vacancies 
even before the programme. This is a meaningful magnitude, given that only 17 percent of firms in the sample experience a vacancy.

Most control variables seem to have no explanatory power. Only firms planning to increase the number of apprenticeships in blue-collar manufacturing occupations in the following years have a higher probability to report a vacancy. If firms invest additional resources in training of disadvantaged youth, vacancies decline. Both of these results seem to be plausible from an empirical point of view.

Table 4 reports findings from the main IV regression for the same sample of firms as in the difference-in-difference approach, specification (2) in Table 3. The first regression documents a linear probability model of the determinants that a firm reports a vacancy (see LPM in table 4). Findings from this regression suggest that only the planned growth of apprentice intakes is significantly and positively related to vacancies. The coefficient for the treatment variable is negative (-0.052) and insignificant (t-value 0.76).

The second and third column displays the first and second stage IV estimation. The instrument works well in statistical terms (the F-statistics is 11.43). The programme effect remains insignificant, although the z-value (1.58) is not far away from significance. The programme effect increases to -0.373 indicating a downward bias in the OLS estimates. This means that participating firms reduced their vacancies as a result of programme participation.

\section{Robustness Checks}

We run a series of robustness checks. For the difference-in-difference approach, appendix table A1 shows the treatment effect and basic regression diagnostics. All regressions in table A1 take into account control variables as in Table 3 specification (2) (the variables which are available in each wave). 
First, we check the robustness of our estimation method and estimate a Probit instead of a linear probability model (table A1, row 2). Second, we check the robustness of the definition of our dependent variable vacancies. Since firms differ in the number of vacancies and the number of apprenticeship positions for blue-collar manufacturing occupation, we replace the vacancy dummy with the proportion of vacancies on all offered apprenticeships in blue-collar manufacturing occupations, vacancy share (row 3). Third we use the information of the number of vacancies and estimate a negative binomial count data model (row 4). Both robustness checks can detect whether the definition of our dependent variable as zero/ one variable drives our results. Fourth, we change the measure of our dependent variable. Instead of purely relying on hard facts, we use a dummy variable of subjective evaluations of training instructors regarding difficulties to find adequate apprentices. This variable may give a further hint whether firms face fewer difficulties to fill apprenticeship positions when participating in the programme. The dummy equals 1 if the training instructor states that he has strong or very strong difficulties to find qualified apprentices (row 5). These robustness checks yield qualitatively similar but again insignificant programme effects. Finally, we apply a difference-indifference model with firm fixed effects and extend the number of observations to one-zero changes (row 6). Including fixed-effects in the extended sample does not change the findings.

We also check the robustness of the IV estimation. Appendix Table A2 first displays the result of estimations with the smaller sample using the full set of control variables (compare Table 2 specification (3)) and second with an extended sample. The extended sample includes those additional participating firms which could not be used in the difference-in-difference framework because they lack a reference period without programme participation. In other words: they participate in 2010 and some of them also in following years. The additional IV estimations indicate that the instrument works and that the treatment effect remains insignificant. 
Summing up, our two different estimation approaches and various robustness checks lead to similar results. We cannot reject the hypothesis that the pilot programme has no impact on vacancies, although the IV estimation is not far from being significant.

\section{Conclusion and Discussion}

The paper evaluates whether a programme designed to integrate disadvantaged youth in apprenticeships in metal- and electronic occupations can reduce recruitment difficulties of apprentices in participating firms. The paper uses a unique panel data set covering more than 85 per cent of eligible member firms of the employer association in the metal and electronic industry in Baden-Württemberg during the period 2010 to 2013. Furthermore, we conduct interviews in six participating and six non-participating member firms as well as with four responsible social workers which helps us to understand firm's decision for programme participation and potential outcomes in more detail.

Treatment and control firms differ in their organization of apprenticeship training. Participating firms are larger, more likely to have an apprenticeship workshop and more likely to employ a full-time training instructor. Furthermore, they are more likely to have a higher capacity and knowledge to train disadvantaged youth. This suggests that participating firms hire disadvantaged youth not primarily to fill vacant positions, but may participate in the programme out of a feeling of social responsibility. This interpretation is in line with the statements of human resource managers in larger participating firms ${ }^{7}$. The paper cannot identify a significant impact of the programme on apprenticeship vacancies using difference-indifference and instrumental variable estimations and performing a number of robustness tests. Although both approaches have their limitations and only a small number of firms participate, the econometric results are unambiguous.

\footnotetext{
${ }^{7}$ A detailed description of the interviews provides the report of Mohrenweiser/ Pfeiffer (2014).
} 
We also compared the average firm-level drop-out and retention rate of the 2010 participating and non-participating firms, the only cohort that had finished apprenticeship till now. We did not find that participating firms are more likely to report drop-outs (11.5 compared to 31 percent), or are more likely to report that apprentices left the training firm immediately after training (the retention rate is 96.1 in participating firms compared to 83.1 percent in nonparticipating firms). At least these numbers do not strengthen the case against firm based training of disadvantaged youth, especially if they receive additional coaching (Mohrenweiser/Pfeiffer 2014 p. 49). However, we are not able to confirm this result with causal analysis, because individual-level data are not available. Future research should investigate comparable firm-based training interventions with individual-level data to additionally assess causal impacts on the level of apprentices.

\section{References}

Backes-Gellner U and Oswald Y (2014). Learning for a bonus: How financial incentives interact with preferences. Journal of Public Economics (forthcoming).

Bonin, H., J. Fries, M. F. Maier, T. Walter (2010), Vorstudie zur Evaluation der Fördermaßnahmen für Jugendliche im SGB II und SGB III. Berlin: Bundesministerium für Arbeit und Soziales.

Blomeyer, D., K. Coneus, M. Laucht, F. Pfeiffer (2009), Initial Risk Matrix, Home Resources, Ability Development and Children's Achievement. Journal of the European Economic Association 7(2-3): 638-648.

Blomeyer, D., K. Coneus, M. Laucht, F. Pfeiffer (2013), Early Life Adversity and Children's Competence Development: Evidence from the Mannheim Study of Children at Risk. Journal of Economics and Statistics 233(4): 467-485.

Caliendo, M., S. Künn, R. Schmidl (2011). Fighting Youth Unemployment: The Effects of Active Labor Market Policies. IZA Discussion Paper, 6222. Bonn.

Cunha, F., J. J. Heckman (2007), The Technology of Skill Formation. The American Economic Review 97 (2): 31-47.

Dolton, P. J., G. H. Makepeace, J. G. Treble (1994), The Youth Training Scheme and the School-to-Work Transition. Oxford Economic Papers 46(4): 629-657. 
Eichhorst W, H. Hinte, U. Rinne (2013), Youth Unemployment in Europe: What to Do about It? IZA policy paper No. 65.

Franz, W., J. Inkmann, W. Pohlmeier, V. Zimmermann (2000), Young and Out in Germany. On Youths‘ Chances of Labor Market Entrance in Germany. In: D. Blanchflower, R. Freeman (Eds.), Youth Unemployment and Joblessness in Advanced Countries. NBER Cambridge, MA, 381-426.

Fries, J., C. Goebel, M. F. Maier (2014), Do Employment Subsidies Reduce Early Apprenticeship Dropout? Journal of Vocational Education and Training (forthcoming).

Inkmann, J., S. Klotz, W. Pohlmeier (1998), Permanente Narben oder temporäre Blessuren? Eine Studie über die langfristigen Folgen eines missglückten Einstiegs in das Berufsleben auf der Grundlage von Pseudo-Panel-Daten. In: F. Pfeiffer, W. Pohlmeier (Eds.), Qualifikation, Weiterbildung und Arbeitsmarkterfolg. Baden-Baden, 223-255.

Mohrenweiser, J. (2012), Which Firms Train Disadvantaged Youth? Empirical Research in Vocational Education and Training 4 (2): 115-130.

Mohrenweiser, J., F. Pfeiffer (2014), Wissenschaftliche Begleitforschung zum Pilotprojekt M+E Einstieg - Forschungsbericht, Zentrum für Europäische Wirtschaftsforschung, Mannheim.

Mohrenweiser J., T. Zwick (2009), Why do firms train apprentices? The net cost puzzle reconsidered. Labour Economics 16(6), 631-637.

Möller J., M. Umkehrer (2014), Are There Long-Term Earnings Scars from Youth Unemployment in Germany? Journal of Economics and Statistics (forthcoming).

Pohl, A., A. Walther (2007), Activating the Disadvantaged. Variations on Addressing Youth Transitions across Europe. International Journal of Lifelong Education 26(5): 553-553

Ryan, P. (2012), Apprenticeship: Between Theory and Practice, School and Workplace. In: M. Pilz (Ed.), The Future of VET in a Changing World Berlin, 402-432.

Schönfeld G., F. Wenzelmann, R. Dionisus, H. Pfeifer, G. Walden (2010). Kosten und Nutzen der dualen Ausbildung aus Sicht der Betriebe. Bertelsmann Verlag, Bielefeld.

Ulrich, J.G, S. Matthes, S. Flemming, R.-O. Granath, E. M. Krekel (2014), BIBB-Erhebung über neu abgeschlossene Ausbildungsverträge zum 30. September (Fassung vom 20.01.2014). Bundesinstitut für Berufsbildung. Bonn.

Wenzelmann, F. (2012), Ausbildungsmotive und die Zeitaufteilung der Auszubildenden im Betrieb. Journal for Labour Market Research 45(2): 125-145. 
Table 1: Variable definition and descriptive statistics

\begin{tabular}{|c|c|}
\hline Variable & Description (mean; sd) \\
\hline & Endogenous variables \\
\hline Vacancy & $\begin{array}{l}\text { Dummy variable equals } 1 \text { if the firm reports a vacant ap- } \\
\text { prenticeship training position in blue-collar manufactur- } \\
\text { ing occupations }(0.17 ; 0.38)\end{array}$ \\
\hline Number of vacancies & $\begin{array}{l}\text { Number of vacancies in apprenticeship training }(0.07 \text {; } \\
0.23 \text { ) (in the } 235 \text { firms with vacancies: } 1.44)\end{array}$ \\
\hline \multirow[t]{2}{*}{ Vacancy share } & $\begin{array}{l}\text { Number of vacancies as a proportion of total intakes } \\
(0.25 ; 0.64) \text { (in the } 235 \text { firms with vacancies: } 0.38)\end{array}$ \\
\hline & Participation, treatment and years \\
\hline Participation & $\begin{array}{l}\text { Dummy variable equals } 1 \text { if the firm participates in the } \\
\text { programme }(0.05 ; 0.22)\end{array}$ \\
\hline Treatment & $\begin{array}{l}\text { Dummy variable equals } 1 \text { if the firm participates in the } \\
\text { particular year in the programme }(0.026 ; 0.16)\end{array}$ \\
\hline \multirow[t]{2}{*}{ Year dummies } & Dummy variables for each year 2011, 2012, 2013 \\
\hline & Control variables set 1 \\
\hline Firm size & Number of employees (743; 3.658) (median: 301) \\
\hline Two year apprenticeship & $\begin{array}{l}\text { Dummy variable equals } 1 \text { if the firm offers two year ap- } \\
\text { prenticeships }(0.11 ; 0.32)\end{array}$ \\
\hline Intake growth & $\begin{array}{l}\text { Dummy variable equals } 1 \text { if the firm plans to increase the } \\
\text { number of apprenticeships in blue-collar manufacturing } \\
\text { occupation in the following year }(0.20 ; 0.40)\end{array}$ \\
\hline Leaving graduates & $\begin{array}{l}\text { Dummy variable equals } 1 \text { if the firm reports that at least } \\
\text { one apprenticeship graduates in blue-collar manufacturing } \\
\text { occupations left the training firm immediately after ap- } \\
\text { prenticeship }(0.07 ; 0.17)\end{array}$ \\
\hline \multirow[t]{2}{*}{ Additional support } & $\begin{array}{l}\text { Dummy variable equals } 1 \text { if at least one apprentice in the } \\
\text { firm receives additional learning support from the voca- } \\
\text { tional school }(\mathrm{abH})(0.51 ; 0.50)\end{array}$ \\
\hline & Control variables set 2 \\
\hline Additional resources & $\begin{array}{l}\text { Dummy variable equals } 1 \text { if the firm states it would invest } \\
\text { additional resources in training of disadvantaged youth } \\
(0.16 ; 0.36)\end{array}$ \\
\hline Additional training & $\begin{array}{l}\text { Dummy variable equals } 1 \text { if the firm trains additional } \\
\text { skills not included in the training curriculum }(0.52 ; 0.50)\end{array}$ \\
\hline Drop-out rate & $\begin{array}{l}\text { Dummy variable equals } 1 \text { if apprentice(s) left before the } \\
\text { final exam in the last three years }(0.17 ; 0.37)\end{array}$ \\
\hline
\end{tabular}


Continued form previous page

\begin{tabular}{|c|c|}
\hline Acquisition & $\begin{array}{l}\text { Dummy variable equals } 1 \text { if the firm cooperates with } \\
\text { schools in technical lessons or vocational preparation } \\
\text { courses }(0.65 ; 0.47)\end{array}$ \\
\hline Low qualified & $\begin{array}{l}\text { Proportion of apprentices in } 3.5 \text { year apprenticeships in } \\
\text { blue-collar manufacturing occupations with a } \\
\text { "Hauptschulabschluss" or a "Berufsvorbereitungsjahr" } \\
\text { before apprenticeship }(0.27 ; 0.33)\end{array}$ \\
\hline High-qualified & $\begin{array}{l}\text { Proportion of apprentices in } 3.5 \text { year apprenticeships in } \\
\text { blue-collar manufacturing occupations with an “Abitur" } \\
(0.15 ; 0.26)\end{array}$ \\
\hline $\begin{array}{l}\text { Apprenticeship work- } \\
\text { shop }\end{array}$ & $\begin{array}{l}\text { Dummy variable equals } 1 \text { if the firm owns an apprentice- } \\
\text { ship workshop }(0.69 ; 0.46)\end{array}$ \\
\hline \multirow[t]{2}{*}{ Full-time instructor } & $\begin{array}{l}\text { Dummy variable equals } 1 \text { if the firm employs an full-time } \\
\text { instructor for apprenticeship training }(0.58 ; 0.69)\end{array}$ \\
\hline & Instrumental variable \\
\hline $\begin{array}{l}\text { Prior contact with train- } \\
\text { ing provider }\end{array}$ & $\begin{array}{l}\text { Dummy variable equals } 1 \text { if the firm already had contact } \\
\text { with the training provider in apprenticeship support pro- } \\
\text { grammes in the beginning of the } 2000 \text { 's }(0.44 ; 0.49)\end{array}$ \\
\hline
\end{tabular}

Source: Südwestmetall Apprenticeship Survey 2010/13, own definitions. N=1,351. 
Table 2: Descriptive statistics for treatment and control group firms

\begin{tabular}{|c|c|c|c|}
\hline Variable & Treatment firms & Control firms & t-value \\
\hline Vacancy & 0.11 & 0.18 & 0.79 \\
\hline Number of vacancies & 0.17 & 0.26 & 0.79 \\
\hline Share of vacancies & 0.03 & 0.07 & 0.83 \\
\hline Firm size (median) & $4,818(719)$ & $514(292)$ & $8.94^{* * *}$ \\
\hline Apprenticeship workshop $^{+}$ & 0.86 & 0.68 & $2.02 * *$ \\
\hline Full-time instructor $^{+}$ & 0.77 & 0.57 & $2.13^{* *}$ \\
\hline Two year apprenticeship & 0.25 & 0.10 & 1.55 \\
\hline Additional support & 0.89 & 0.49 & $4.66^{* * *}$ \\
\hline Additional resources $^{+}$ & 0.25 & 0.15 & 1.00 \\
\hline Additional training $^{+}$ & 0.67 & 0.52 & 1.47 \\
\hline Low qualified $^{+}$ & 0.31 & 0.27 & 0.48 \\
\hline High-qualified $^{+}$ & 0.07 & 0.15 & 1.37 \\
\hline Drop-out rate $^{+}$ & 0.31 & 0.17 & 1.42 \\
\hline Intake growth & 0.31 & 0.19 & 1.14 \\
\hline Leaving graduates & 0.08 & 0.07 & 0.12 \\
\hline Acquisition $^{+}$ & 0.81 & 0.65 & $1.69 *$ \\
\hline $\begin{array}{l}\text { Prior contact with training } \\
\text { provider }\end{array}$ & 0.81 & 0.42 & $4.10 * * *$ \\
\hline Observations & 72 & 1,279 & \\
\hline
\end{tabular}

${ }^{+}$fewer observations (72 treatment and 1,011 in control group); ${ }^{*} \mathrm{p}<0.01,{ }^{* *} \mathrm{p}<0.05,{ }^{* * *} \mathrm{p}<0.01$. Source: Südwestmetall Apprenticeship Survey 2010/13, own calculations. 
Table 3: Difference-in-Difference Estimation

\begin{tabular}{|c|c|c|c|c|c|c|}
\hline & \multicolumn{2}{|c|}{$(1)$} & \multicolumn{2}{|c|}{$(2)$} & \multicolumn{2}{|c|}{ (3) } \\
\hline & Coeff. & $\mathrm{t}$ & Coeff. & $\mathrm{t}$ & Coeff. & $\mathrm{t}$ \\
\hline Treatment & 0.064 & $(0.80)$ & 0.076 & $(0.92)$ & 0.092 & $(1.06)$ \\
\hline Participation & $-0.101^{* *}$ & $(2.02)$ & $-0.141^{* *}$ & $(2.56)$ & $-0.114^{* *}$ & $(2.08)$ \\
\hline 2011 & -0.019 & $(0.74)$ & -0.013 & $(0.50)$ & -0.002 & $(0.08)$ \\
\hline 2012 & -0.009 & $(0.31)$ & 0.015 & $(0.51)$ & 0.041 & $(1.24)$ \\
\hline 2013 & -0.030 & $(1.06)$ & -0.011 & $(0.39)$ & 0.017 & $(0.57)$ \\
\hline Firm size & & & 0.012 & $(1.07)$ & 0.001 & $(0.16)$ \\
\hline Firm size squared & & & -0.000 & (1.39) & -0.000 & $(0.59)$ \\
\hline Two year apprenticeships & & & 0.052 & (1.18) & 0.056 & $(1.25)$ \\
\hline Intake growth & & & $0.146 * * *$ & $(4.42)$ & $0.135 * * *$ & $(3.72)$ \\
\hline Leaving graduates & & & 0.030 & $(0.52)$ & 0.013 & $(0.21)$ \\
\hline Additional support & & & 0.015 & $(0.60)$ & 0.017 & $(0.64)$ \\
\hline Additional resources & & & & & $-0.072 * *$ & $(2.22)$ \\
\hline Additional training & & & & & 0.044 & $(1.54)$ \\
\hline Drop-out rate & & & & & $0.076^{*}$ & $(1.71)$ \\
\hline Acquisition & & & & & 0.027 & $(0.84)$ \\
\hline Low qualified & & & & & -0.062 & $(1.63)$ \\
\hline High-qualified & & & & & 0.022 & $(0.44)$ \\
\hline Apprenticeship workshop & & & & & -0.046 & $(1.04)$ \\
\hline Full-time instructor & & & & & -0.036 & $(0.82)$ \\
\hline Constant & $0.192 * * *$ & $(8.24)$ & $0.131 * * *$ & $(4.91)$ & $0.149 * * *$ & $(3.48)$ \\
\hline R-sqr & 0.00 & & 0.03 & & 0.05 & \\
\hline Number of Observations & 1,351 & & 1,351 & & 1,083 & \\
\hline
\end{tabular}

Dependent variable: Vacancy (dummy equals 1 if the firm reports a vacancy); Method: OLS Difference-in-Difference; standard errors clustered on firm-level $* \mathrm{p}<0.01,{ }^{* *} \mathrm{p}<0.05$, ${ }^{* * *} \mathrm{p}<0.01$. Source: Südwestmetall Apprenticeship Survey 2010/13, own calculation. 
Table 4: IV Estimation

\begin{tabular}{lcccccc}
\hline \hline & \multicolumn{2}{c}{ LPM } & \multicolumn{3}{c}{ IV } \\
\hline & \multicolumn{5}{c}{ Second stage } & \multicolumn{2}{c}{ First stage } \\
\hline Coeff. & $\mathrm{t}$ & Coeff. & $\mathrm{z}$ & Coeff. & $\mathrm{z}$ \\
\hline $\begin{array}{l}\text { Prior contact with train- } \\
\text { ing provider }\end{array}$ & & & & & $0.662^{* * *}$ & $(3.32)$ \\
\hline Treatment & -0.052 & $(0.76)$ & -0.373 & $(1.58)$ & & \\
2011 & -0.011 & $(0.41)$ & 0.005 & $(0.14)$ & 7.389 & $(0.04)$ \\
2012 & 0.019 & $(0.66)$ & 0.033 & $(1.03)$ & 7.379 & $(0.04)$ \\
2013 & -0.004 & $(0.16)$ & 0.004 & $(0.13)$ & 7.113 & $(0.04)$ \\
Firm size & 0.008 & $(0.79)$ & 0.016 & $(1.49)$ & $0.155^{* * *}$ & $(3.08)$ \\
Firm size squared & -0.0001 & $(1.18)$ & -0.000 & $(1.71)$ & $-0.002^{* * *}$ & $(2.60)$ \\
Two year apprenticeships & 0.052 & $(1.17)$ & $0.056^{*}$ & $(1.67)$ & 0.406 & $(1.88)$ \\
Intake growth & $0.143^{* * *}$ & $(4.33)$ & $0.143^{* * *}$ & $(5.50)$ & -0.091 & $(0.39)$ \\
Leaving graduates & 0.029 & $(0.51)$ & 0.033 & $(0.55)$ & 0.276 & $(0.51)$ \\
Additional support & 0.010 & $(0.42)$ & 0.022 & $(0.98)$ & $1.039^{* * *}$ & $(3.80)$ \\
\hline Constant & 0.128 & $(4.83)$ & $0.116^{* * *}$ & $(4.10)$ & -10.532 & $(-0.06)$ \\
\hline Pseudo R-sqr/ F-Statistic & 0.02 & & & & 11.43 & \\
\hline Number of Observations & 1,351 & & 1,351 & & 1,351 & \\
\hline \hline
\end{tabular}

Dependent variable: Vacancy (dummy equals 1 if the firm reports a vacancy) (LPM and second stage IV), programme participation (first stage); standard errors clustered on firm-level ${ }^{*} \mathrm{p}<0.01,{ }^{* *} \mathrm{p}<0.05$, $* * * \mathrm{p}<0.01$.

Source: Südwestmetall Apprenticeship Survey 2010/13, own calculations. 
Appendix

Table A1: Robustness regressions for Difference-in-Difference

\begin{tabular}{|c|c|c|c|c|}
\hline & Coeff. & $\mathrm{z}$ & $\begin{array}{c}\text { (Pseudo) } \\
\mathrm{R}^{2}\end{array}$ & $\mathrm{~N}$ \\
\hline Vacany - Probit & 0.405 & $(0.89)$ & 0.04 & 1,351 \\
\hline Vacancy share - Tobit & 0.516 & $(0.17)$ & 0.03 & 1,351 \\
\hline Number of vacancies - Negative binomial & 0.910 & $(0.32)$ & & 1,351 \\
\hline Subjective evaluation - OLS & -0.040 & $(0.64)$ & 0.03 & 1,264 \\
\hline $\begin{array}{l}\text { Vacancy with firm-fixed effects and one- } \\
\text { zero changers - LPM }\end{array}$ & 0.063 & $(0.84)$ & 0.01 & 1,531 \\
\hline
\end{tabular}

Dependent variable: Vacancy (dummy equals 1 if the firm reports a vacancy) (row 2); Share of vacancies on total new intakes (row 3), number of vacancies (row 4) and Dummy if the firm reports to face strong or very strong difficulties to find adequate apprentices (row 5); Source: Südwestmetall Apprenticeship Survey 2010/13, own calculations.

Table A2: Robustness regressions for IV

\begin{tabular}{llcccc}
\hline \hline Sample & & Coef. & $\mathrm{z}$ & F-stat & $\mathrm{N}$ \\
\hline Small & First stage (Instrument) & $0.634^{* * *}$ & $(3.03)$ & 10.31 & 1,081 \\
& Second stage (Treatment) & -0.199 & $(0.86)$ & & 1,081 \\
\hline \multirow{2}{*}{ Extended } & First stage (Instrument) & $1.107^{* * *}$ & $(9.36)$ & 44.44 & 1,634 \\
& Second stage (Treatment) & 0.017 & $(0.17)$ & & 1,634 \\
\hline \hline
\end{tabular}

Dependent variable: Vacancy (dummy equals 1 if the firm reports a vacancy) (second stage), program participation (first stage); Method: IV probit; standard errors clustered on firm-level; control variables: participation, time variables, firm size, firm size squared, two year apprenticeship, intake growth, leaving graduates and additional support (extended sample) and additionally additional resources, additional training, drop-out rate, acquisition, low-qualified, high-qualified, apprenticeship workshop, full-time instructor (small sample); ${ }^{*} \mathrm{p}<0.01,{ }^{* *} \mathrm{p}<0.05$, *** $\mathrm{p}<0.01$.

Source: Südwestmetall Apprenticeship Survey 2010/13, own calculations. 